Diyala Journal of Engineering Sciences

Journal homepage: https://en.enginmag.uodiyala.edu.iq/

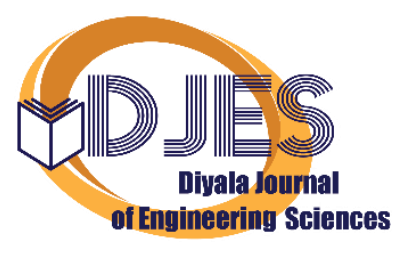

ISSN: 1999-8716 (Print); 2616-6909 (Online)

\title{
Effect of Replacing the Main Reinforcement by Sheet Steel Plate in Reinforced Concrete Beams
}

\author{
Khalid I. Qaddoory ${ }^{1,}{ }^{*}$, Ahmed A. Mansor ${ }^{2}$, Bilal J. Noman ${ }^{3}$, Wisam D. Salman ${ }^{4}$, Ahlam S. Mohammed ${ }^{5}$ \\ ${ }^{1,2,4}$ Department of Civil Engineering, University of Diyala, 32001 Diyala, Iraq \\ ${ }^{3}$ Department of Civil Engineering, University of Baghdad, Baghdad, Iraq \\ ${ }^{5}$ Department of Civil Engineering, University of Technology, Baghdad, Iraq
}

\section{ARTICLE INFO}

\section{Article history:}

Received 17 July 2021

Accepted 21 August 2021

Keywords:

Flexural reinforcement; Steel plates;

Yield load; Ultimate load; Crack load

\begin{abstract}
In recent years, new methods have developed utilizing steel plates instead of deformed steel bar reinforcement in the concrete beams. This paper presents the utilization of a new proposed approach for replacing the main flexural reinforcement concrete beams by steel checker plates of $(6 \mathrm{~mm})$ thickness. Four reinforced concrete beams were cast and tested under two-point load. All beams had the same cross-sectional area of reinforcement and the dimensions of $210 \mathrm{~cm}$ in length, $35 \mathrm{~cm}$ in height and $25 \mathrm{~cm}$ in width. The result show there was a reduction in crack load, yield load, and ultimate load of steel plate as compared to steel bar, Whereas increased with increasing cross-sectional area of the steel. Once, the increment in crack load and yield load of steel plate were $25.5 \%$ and $16,67 \%$ more than steel bar whereas the same increment was found in ultimate load for both steel bar and steel plate. The measured crack load and ductility for steel plate was $16.7 \%$ more than steel bar when increasing cross-sectional area of steel. The deflection past of failure for steel plate has a considerable deflection before failure than steel bar. Finally, the observations show cracks have been much wider and less in range for all steel plate samples in comparison with the steel bar.
\end{abstract}

\section{Introduction}

Concrete beams use as a significant part of structural frames has witnessed a noticeable improvement since last decades. The strengthened concrete structure includes beams over openings to hold horizontal loads. In addition, there was a limit studies in literature have been studied the utilizing of steel plate as a flexural member up to date. Although it has been used to strengthen the reinforced concrete beams. the external or internal steel plate instead of bending stiffeners. Recently steel plate has been used in application of simply supported beam and continuous beam. However, steel plate was half cheaper than steel bar reinforcement on average.

\footnotetext{
* Corresponding author.

E-mail address: aamansor@engineering.uodiyala.edu.iq DOI: $10.24237 /$ djes.2021.14312
}

Alfeehan, 2014[1] presented a practical and theoretical research on the effect of replacing tension reinforcement on cracking, structural deformation and maximum resistance. The results indicate that steel sheets were used as the external reinforcement showed that the measured displacement of the center of the beam was restricted and increased plate thickness resulted in increased beam acceptance. The steel substitutions rate decreased by $33 \%, 67 \%$ and $100 \%$ respectively by $7.7 \%$ and $4.6 \%$, resulting in a $12.5 \%$ decrease.

Thamrin and Sari [2] reported the results of an experimental study on behavior of reinforced concrete beams strengthened with flexural bonded steel plates, and test results showed that the stiffness of the beam and flexural in steel plates linked to the web growth by means of 
value ranging from 6 to 28 percent. Mansor, et al., $2018[3,4,5]$ presents an experimental work on the conduct of bubbled wide strengthened concrete beams of four longitudinal plates of $3 \mathrm{~mm}$ thickness, and the measurement became $165 \mathrm{~mm} * 1700 \mathrm{~mm}$. The experimental outcomes display that during legs the outside strain of longitudinal and transvers plate was $17 \%$ and $2 \%$ respectively much less than strain at yield of stirrups and the ultimate was much less approximately $62 \%$ and $68 \%$ respectively.

Hadi, et al, 2018 [6] found out the outcomes of an experimental program of strengthened concrete beams with steel plate checker and its overall performance in comparison to specimen strengthened with deformed steel bars, in comparison to the reference sample, Samples strengthened with a horizontal plate confirmed lots extra ductility. Samples have been vertical plate reinforcement confirmed susceptible ductility, with eventual excessive reduction in ultimate load limit state. All plate-strengthened specimens received access ultimate loads variety from 90 to $96 \%$ of theoretical values.

Zuhdiy and Abbas, 2021 [7] studied the structural behavior of the corrugated steel box girder with a horizontal and vertical corrugation using corrugated steel plates and studied the effect of the cell shape. Experimental results shown that the use of vertical and horizontal corrugated steel plates increase the ultimate load by $(7,14 \%$ and $11,03 \%)$, respectively compared to the control box girder.

In this research, because of the rapid development of computer numerical control
(CNC) manufacturing and the high cost and the time involved certain difficulties in longitudinal reinforcement, efforts were made to find new techniques for longitudinal reinforced concrete beams which depend on the application of the elongated steel sheet plate as bending reinforcement instead of a deformed steel bar. The goal of experimental will be investigating the effect of replacing the main reinforced concrete beams by checker steel plates. And monitoring the outcome of the (crack, yield and ultimate load) and strain characteristics in longitudinal reinforcement and concrete.

\section{Methodology}

\section{2-1 Description of beams specimens and details}

Four reinforced concrete beams were casted and designed to fail in flexure. All specimens have the same cross section and the mount of reinforcement. They had an overall length of $2100 \mathrm{~mm}$, overall depth of $350 \mathrm{~mm}$, and width of $250 \mathrm{~mm}$. The two reference beams specimen was reinforced with 2- $\varnothing 16$ and 2-Ø20 steel bars and the two others reinforced with $6 \mathrm{~mm}$ thickness of steel plate in longitudinal direction (tensile) reinforcement within the bottom face of concrete beams. Additionally, to insure there no shear failure inside the section, $10 \mathrm{~mm}$ stirrups at $125 \mathrm{~mm}$ spacing center to center was provided in the beams. The beam details were shown in figure 1 and Table 1 sum up the description names of beam specimens.

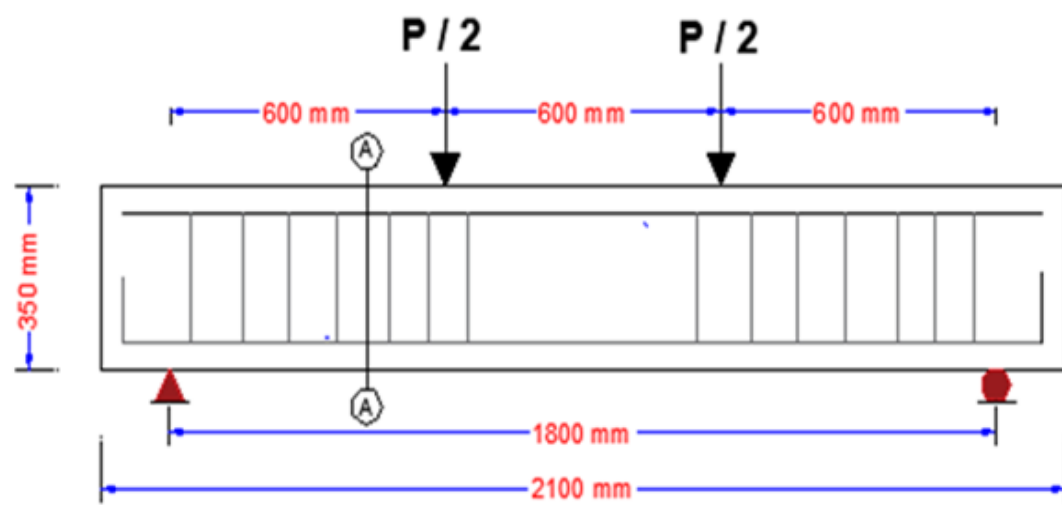

(a)

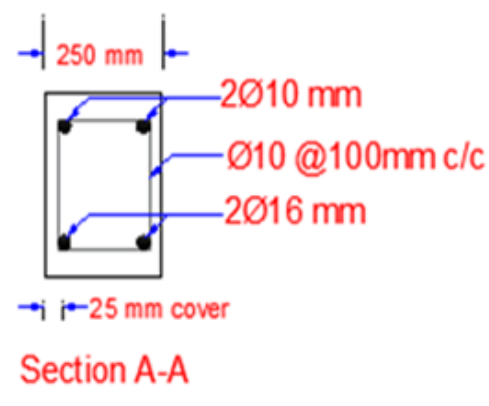

(b)

Figure 1. Details and cross section of reference beams 
Table 1: The description names and details of beams specimens

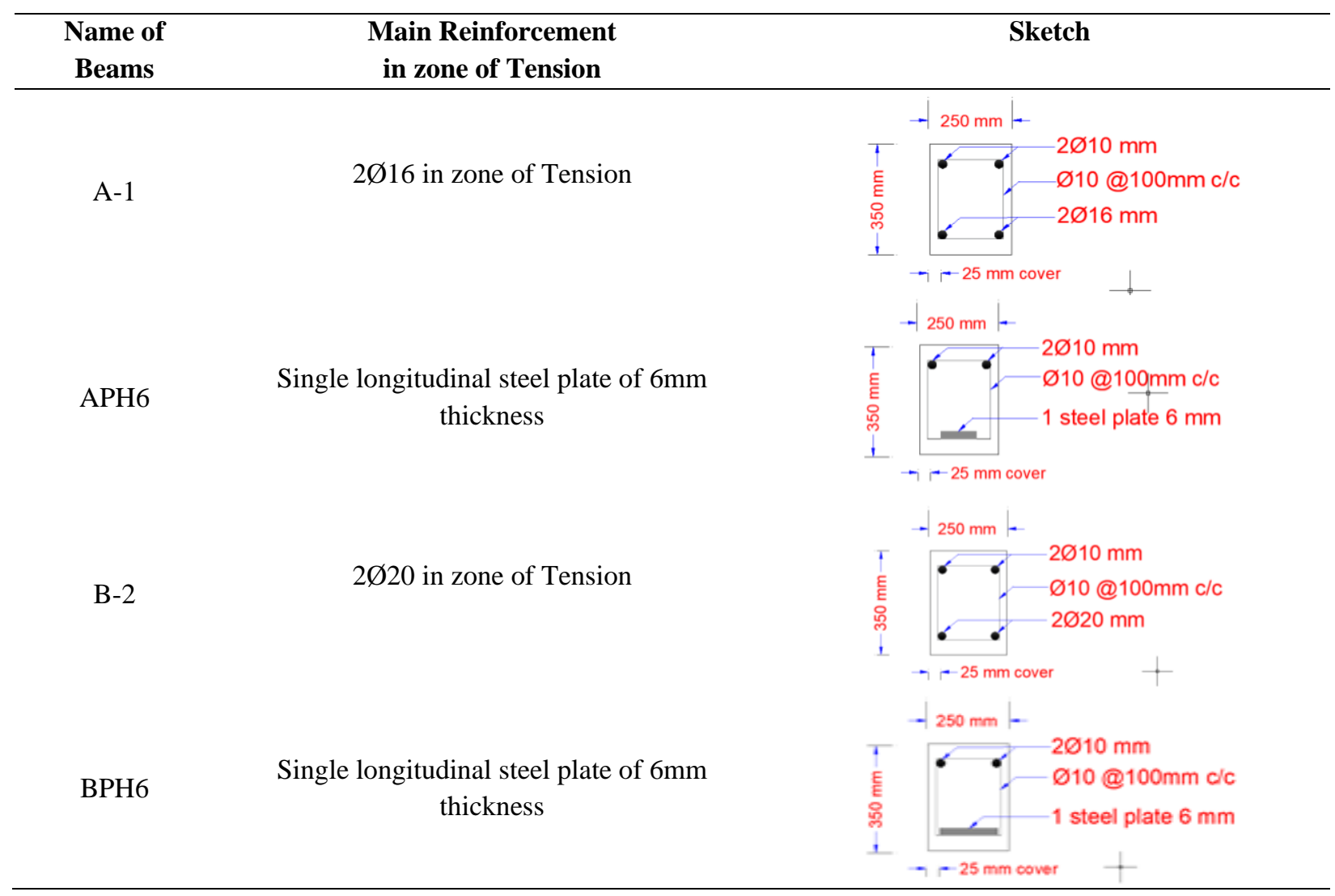

\subsection{Concrete ingredients}

Industrial emblem of Tasluoja which was assessed as kind I of Portland cement turned into used within the experimental of the present study. The usage of cement in the current study turned into observed to fulfil the ASTM C15016 [8]. After (forty-eight hours), the beams had been protected with canvas and dispersed constantly with tap water. The temperature of water within the curing tank was ready $\left(23^{\circ}\right)$ consistent with ASTM C192 [9] for (28days). The specimens had been white painted and marked once they get sufficient curing to allow for the commentary of cracks increase via testing. self-compacting Concrete with compressive strength of $f c^{\prime}=30 \mathrm{MPa}$.

The natural sand that used as fine aggregate and the coarse, which have been delivered from Al-Sudor region, Diyla Governorate, Iraq. Coarse aggregate $\max (10 \mathrm{~mm})$. The fine and coarse aggregates meet the boundaries of ASTM C33-11 [10]. The detail of mix proportion as shown in table (2).

Table 2: Mix proportions

\begin{tabular}{|c|c|c|c|c|c|c|}
\hline Material & $\begin{array}{l}\text { Cement } \\
(\mathrm{kg} / \mathrm{m3})\end{array}$ & $\begin{array}{c}\text { Coarse aggregate } \\
(\mathrm{kg} / \mathrm{m} 3)\end{array}$ & $\begin{array}{c}\text { Fine aggregate } \\
(\mathrm{kg} / \mathrm{m3})\end{array}$ & $\begin{array}{c}\text { Water } \\
(\mathrm{kg} / \mathrm{m3})\end{array}$ & w/c & $\begin{array}{l}\text { Slump } \\
(\mathrm{mm})\end{array}$ \\
\hline C30 & 490.0 & 897.0 & 700.0 & 248 & $50 \%$ & $120.0 \mathrm{~mm}$ \\
\hline
\end{tabular}

\subsection{Steel reinforcement and steel plates}

Tensile tests of steel reinforcement of three samples $(450 \mathrm{~mm})$ in length were detected for each drop test performed using the available testing machine. According to ASTM A615/A615M-05a and ASTM A496-02, the average yield and ultimate stresses were listed in Table (3).

Steel plates were tested in Engineering College of Baghdad University according to ASTM A370-05-a specification. Table (4) reveals experimental results of testing typical samples with a length of $450 \mathrm{~mm}$. 
Table 3: Yield and ultimate stresses and elongations of steel bars used

\begin{tabular}{cccccc}
\hline $\begin{array}{c}\text { Nominal bar } \\
\text { diameter (mm) }\end{array}$ & $\begin{array}{c}\text { Measured } \\
\text { Diameter (mm) }\end{array}$ & $\begin{array}{c}\text { Bar cross } \\
\text { area(mm2) }\end{array}$ & $\begin{array}{c}\text { Yield stress } \\
\text { (MPa) }\end{array}$ & $\begin{array}{c}\text { Ultimate stress } \\
\text { (MPa) }\end{array}$ & $\begin{array}{c}\text { Elongation at } \\
\text { ultimate stress }\end{array}$ \\
\hline 10.0 & 10.20 & 78.5 & 610 & 725 & $11.70 \%$ \\
16.0 & 15.80 & 201.06 & 528 & 642 & $13.20 \%$ \\
20.0 & 19.80 & 314.1 & 442 & 699 & $15.50 \%$ \\
\hline
\end{tabular}

Table 4: Result of testing of steel plate

\begin{tabular}{ccccc}
\hline $\begin{array}{c}\text { Thickness of steel plate } \\
(\mathbf{m m})\end{array}$ & $\begin{array}{c}\text { Measured Thickness } \\
(\mathbf{m m})\end{array}$ & $\begin{array}{c}\text { Yield stress } \\
(\mathbf{M P a})\end{array}$ & $\begin{array}{c}\text { Ultimate stress } \\
(\mathbf{M P a})\end{array}$ & $\begin{array}{c}\text { \% Elongation at } \\
\text { ultimate stress }\end{array}$ \\
\hline 4.0 & 3.80 & 400.0 & 545.60 & $22.50 \%$ \\
5.0 & 4.80 & 416.50 & 563.2 & $24.0 \%$ \\
6.0 & 5.80 & 433.60 & 580.0 & $25.30 \%$ \\
\hline
\end{tabular}

\subsection{Beam fabrication, test setup, and instrumentation}

Longitudinal bars of $(2 \varnothing 16 \mathrm{~mm}$ and $2 \varnothing 20 \mathrm{~mm}$ ) become used at the bottom reinforcement of the two-reference beam. even as the longitudinal deformed bar of $(2 \varnothing 10 \mathrm{~mm})$ relied on the top reinforcement to preserve the stirrups and preserve them in function for all beams of a traditional layout. And the two other samples regarding the alternative of deformed steel reinforcement with a steel plate within the longitudinal course. All steel plates were riveted with reinforcement and welded with stirrups from the bottom at four positions consistent with plate. The reinforcement for all samples as proven as shown in Figure (2). The four beams were simply supported over a span of $2100 \mathrm{~mm}$ and the loads were applied using a $600 \mathrm{kN}$ hydraulic testing system (Jet Materials Ltd. Company). The deflected shape of the beam at the mid-span and under point load applied, was measured by three dial gauges.

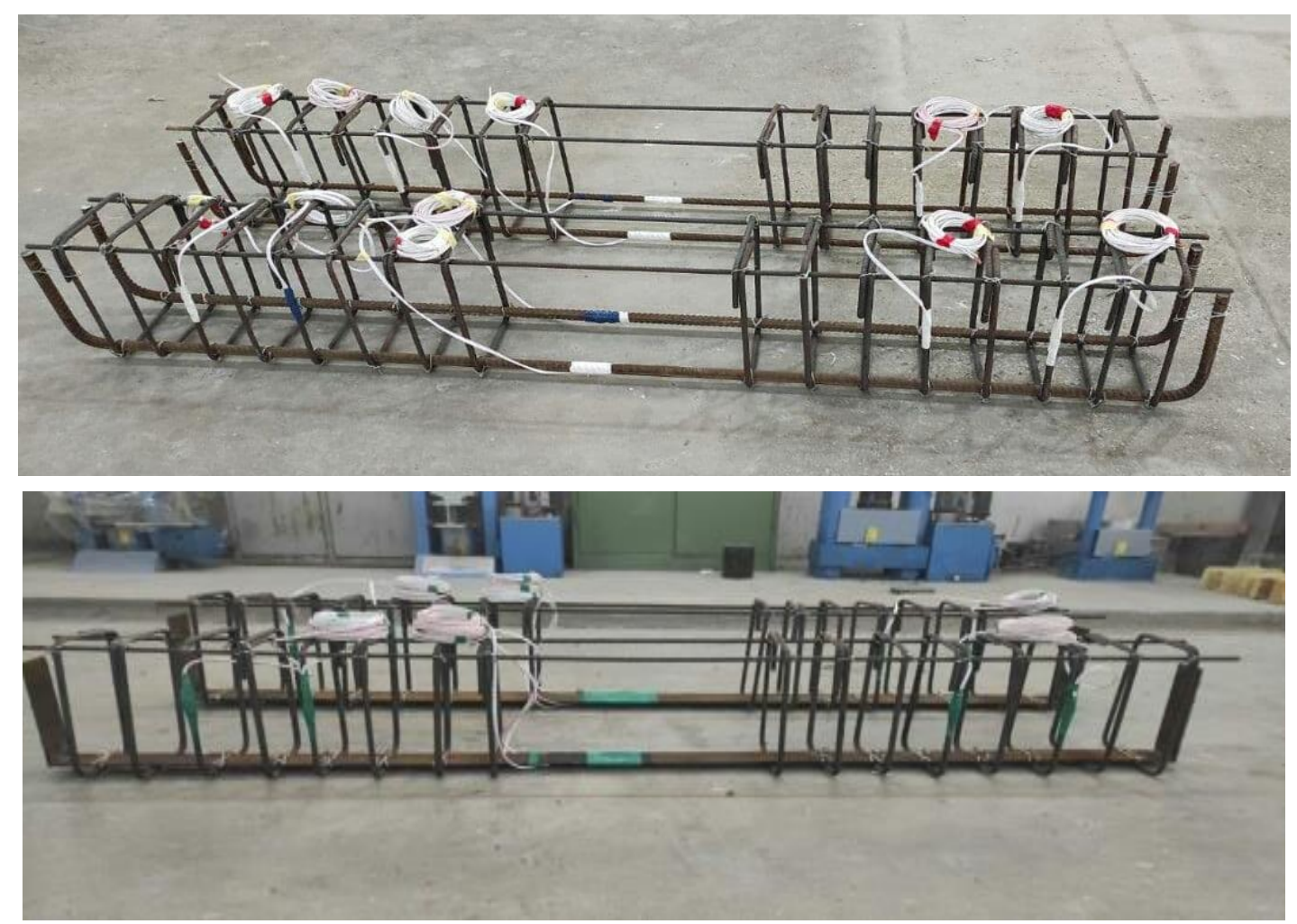

Figure 2. Steel reinforcement and steel plate arrangement 


\subsection{Test procedure}

To test all beams, a hydraulically universal $(600 \mathrm{kN})$ test equipment was used. Positions were checked by the supporting and load points beams. The LVDT was fixed to the center of the upper surface of the specimens after establishing the beam machine and strain gage with the data logger. In order to ensure uniform surface, rubber pads were placed under line loads. Twopoint test load were considered as indicated as shown in Figure (3). The position of the strain gage was supported in the center of the two middle reinforcing bars for main longitudinal steel. At the beginning of the test day the stain measuring wires were connected to the data logger. The concrete strain was measured by utilizing the PFL-30-11 electrical strain gauge with $120 \Omega$ resistance, $30 \mathrm{~mm}$ long and $10 \mathrm{~mm}$ wide dimensions. In the central top of the beam sample, the steel strain gages were placed.

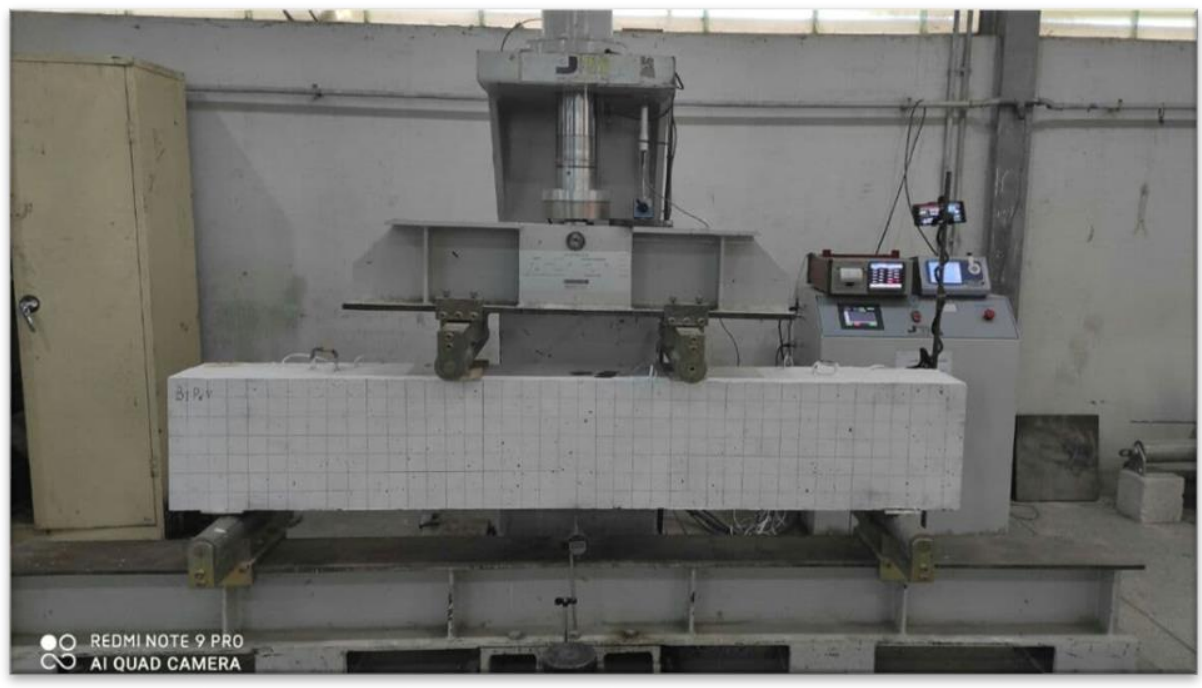

Figure 3. Position of beams in the load-testing machine

\section{Experimental results and discussion}

The measurements from testing the beam specimens were used to obtain actual information that have been used in the analysis of the beams specimens their values were shown in table (5).

Table 5: Hardened properties of the four specimens

\begin{tabular}{ccccc}
\hline $\begin{array}{c}\text { Specimen } \\
\text { designation }\end{array}$ & $\begin{array}{c}\mathbf{f}^{\prime} \mathbf{c}(\mathbf{M P a}), \text { cylinders } \\
\text { 28 days }\end{array}$ & $\begin{array}{c}\text { fct (MPa), } \\
\text { 28 days cylinders }\end{array}$ & $\begin{array}{c}\text { fr (MPa), at } \\
\text { 28 days }\end{array}$ & $\begin{array}{c}\text { modulus of } \\
\text { elasticity,Ec (MPa) }\end{array}$ \\
\hline A-1 & 32.46 & 2.96 & 3.91 & 26779 \\
APH6 & 33.896 & 3.118 & 5.813 & 27363 \\
B-2 & 32.465 & 2.958 & 3.908 & 26779 \\
BPH6 & 33.896 & 3.118 & 5.813 & 27367 \\
\hline
\end{tabular}

\subsection{The behaviour of beams subjected to loading}

Two load points have been subject to the beam, as described earlier. Three dial gages were used to read the deflection and data loggers were applied to monitor the strain in steel and concrete and the crack widths were read using a micro crack reader at loading $10 \mathrm{kN}$ for beam failure. The development track of strain, deflection, and cracks width at each loading level was measured directly on the beam to follow cracking sequence, cracking growth and cracking pattern $[11,12]$.

\subsection{The result of specimens}

For all specimen the ultimate load, deflection, first crack yield load and deflection at first crack were listed in Table (6). The first crack load that formed was carefully 
determined. The analysis of the results will focus on and discusses the following:

a) Capacity for load beams (crack load, yield load and ultimate load).

b) Mid-span deflection and ductility of specimen. c) Strain in steel plates and longitudinal reinforcement.

d) Pattern of cracking (crack width, crack spacing, and number of cracks).

Table 6: Summary of test results for specimens

\begin{tabular}{cccccccccc}
\hline $\begin{array}{c}\text { Specimen } \\
\text { designation }\end{array}$ & $\begin{array}{c}\text { Dimension } \\
\text { of steel } \\
\text { plate (mm) }\end{array}$ & $\begin{array}{c}\text { 1st flex. } \\
\text { Cracking } \\
\text { load Pcr } \\
(\mathbf{k N})\end{array}$ & $\begin{array}{c}\mathbf{P y} \\
(\mathbf{k N})\end{array}$ & $\begin{array}{c}\mathbf{P u} \\
(\mathbf{k N})\end{array}$ & $\begin{array}{c}\Delta \mathbf{c r} \\
(\mathbf{m m})\end{array}$ & $\begin{array}{c}\Delta \mathbf{y} \\
(\mathbf{m m})\end{array}$ & $\begin{array}{c}\Delta \mathbf{u} \\
(\mathbf{m m})\end{array}$ & $\begin{array}{c}\text { Ductilit } \\
\mathbf{y} \\
\Delta \mathbf{u}\end{array}$ & $\begin{array}{c}\text { Failure } \\
\text { mode }\end{array}$ \\
\hline A-1 & $2 \varnothing 16$ bars & 45 & 215.0 & 252.70 & 2.37 & 11.350 & 18.5 & 1.630 & Flexural \\
APH6 & $1(6 \times 66.6)$ & 30 & 105.0 & 151.50 & 3.11 & 8.75 & 28.64 & 3.270 & Flexural \\
B-2 & $2 \varnothing 20$ bars & 60 & 270.0 & 359.0 & 5.65 & 14.39 & 24.88 & 1.720 & Flexural \\
BPH6 & $1(6 \times 105)$ & 45 & 160 & 213.0 & 4.62 & 10.9 & 35.42 & 3.240 & Flexural \\
\hline
\end{tabular}

\subsection{Cracking load}

The crack load for APH6 and BPH6 was reduced by approximately $33.3 \%$ and $25 \%$ compared to references A-1 and B-2. The measured crack load for specimens B-2, compared to A-1, and for APH6 compared to BPH6 was also increased by $33,33 \%$ and $50 \%$ respectively. The ductility of specimens BPH6 and APH6 showed an increase in approximately of $50 \%$ above A-1 and B-2 respectively. The replacement of the reinforcement bars with the steel plate effects was also apparent from the comparison of cracks patterns of the steel plate samples and reinforced steel specimens, indicating that this reduces the ultimate load and thereby reducing the crack load.

The cracks were wider and lower for the steel plate related to A-1 and B-1 specimens, because the dowel-action that considered to be one of the main factors which reduce the split in the plate was lower than that of the steel reinforced specimen, which was arising from the high bond of the bars compared with the steel plate. It was worth mentioning that for all specimens the characteristics of the concrete were the same which neglect the influence of other factors related to the concrete properties that might lead to fractures.

\subsection{Yielding load}

In the bases of results as shown in table (6) the yielding load values that have been obtained from load deflection figures. Where equivalent cross-sectional area of steel plate has been used, it can be seen that the yield load for APH6 and BPH6 was reduced by around $51 \%$ and $40.7 \%$ compared to the A-1 and B-2 respectively. This drop was because the strength of the steel plate was different from that of the steel reinforced bar, which was more efficient than the former [13]. In comparison with A-1, the yield load for the B-2 specimens was raised by $26 \%$. specimens BPH6 has shown an increase of about 52.38\% more than APH6.

\subsection{Ultimate load}

Table (6) shows the ultimate load that has been resulted from load deflection figures. It was clear that, compared to A-1 and B-1, the ultimate load decreased respectively by $40 \%$ and $40,6 \%$ for APH6 and BPH6. This can be attributed to the deference between the ultimate load on the steel bars and steel plates, where the steel bar was stronger than the previous one [14]. Furthermore, the ultimate load of the B-2 specimen was $42.06 \%$ higher than $\mathrm{A}-1$. The specimen BPH6 has shown an increase of about $40.59 \%$ more than APH6. 


\subsection{Ductility index}

It was clear from table (6) and noticeable that the ductility of APV6 and BPH6 are increased by $3.27 \%$ and $3.23 \%$ as compared with A-1 and B-2 respectively. This readily supports a definition of the ductility index to which considerable deflection was expected before failure. It was clear that deflection past the failure load was increased with the increase of the steel plate thickness.

\subsection{Load versus deflection relationship}

The deflection values monitored at yield load and ultimate load that have been attained from the diagram of load deflection are shown in table (6). Clearly, as in table (6) that at yield load the deflection has been increased in specimens when using steel plate by about $55 \%$ and $16.14 \%$ for APH46 and BPH6 as compared with A-1 and B-2 respectively. This can be understood as steel plate ductility was larger than steel bars. Furthermore, from load deflection diagrams the deflection at yield loads obtained was increased by $27 \%$ for the specimen B-2 as compared with A-1, The specimen BPH6 has shown an increase of about $24.17 . \%$ more than APH6.

It was also clear from Table (6) that at ultimate load the deflection was decreased in each specimen when using steel plate by about $23 \%$ and $23.934 \%$ for APH64 and BPH6 as compared with A-1 and B-2 respectively, this can be seen that the ductility of the steel plate has bigger compared to the steel reinforcement bars. The deflection at ultimate loads was larger by $34.5 \%$ for the specimens B-1, compared with A-2, and specimen APH6 has shown an increase of about $23.65 \%$ more than BPH6 due to the increasing of cross-sectional area of steel. Figures (4) shows the load-deflection curves specimens. The diagram shows that the loaddeflection curve was conducted straight up to the value where the crack was conducted for all the models, and the yield strength of each sample steel plate will be controlled beyond the yield load. Also, the curve shows non-linear behaviour when loading was increased as it exceeds the point load at which it yields.

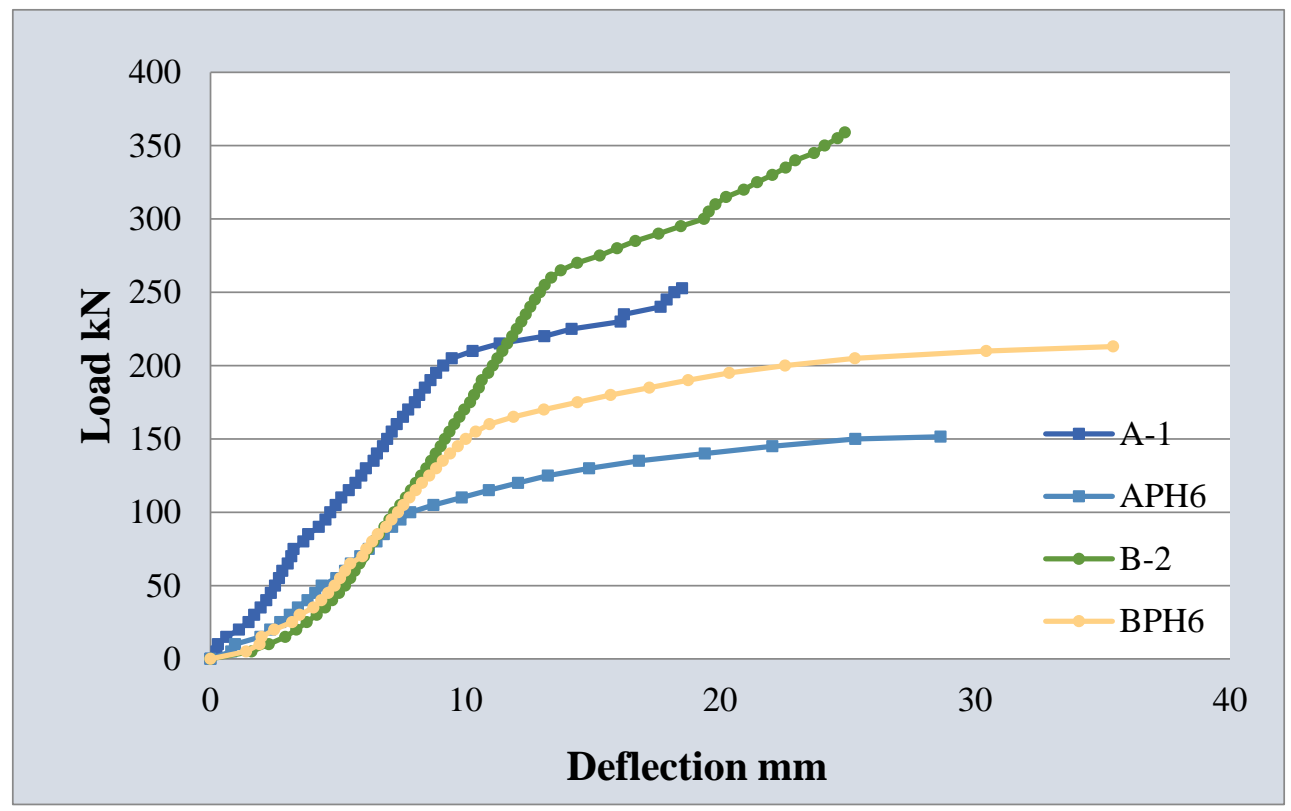

Figure 4. Load - central deflection for specimens

\subsection{Strain in longitudinal reinforcement}

It can be observing from Table (7) that the strain in longitudinal steel bar at crack load was decreased between samples A-1 and B-2 by $61.29 \%$. The specimen BPH6 has an increase of
$78 \%$ compared to APH6. It can be seen from Table (7) that the strain in longitudinal bars at yield load was increased between specimens B2 and A- 1 by $15.47 \%$. Also, the specimen BPH6 has an increase of $4.7 \%$ related to APH6. Furthermore, the strain in the longitudinal bars 
at ultimate load was increased between specimens A-1 and B-2 by $10.10 \%$. The specimen BPH6 has a decrease of $20.25 \%$ compared to APH6.

\subsection{Strain in compression face of concrete}

In addition, the strain in concrete (compression) at load crack was increased by $50 \%$ and $28.23 \%$ for specimens B-2 and BPH6 as compared to A-1 and APH6. At yield load the strain decreased by $11.7 \%$ between the A-1 and B-2 specimens. Whereas, an increase by $6 \%$ of BPH6 as compared with APH6. Moreover, the result shows that the of longitudinal reinforcement at the yield load was reduced by $11 \%$ between specimens A-1 and B-2. Compared with APH6, the BPH6 was $1.8 \%$ higher.

Table 7: Strain characteristics in longitudinal reinforcement and concrete

\begin{tabular}{|c|c|c|c|c|c|c|c|c|c|c|c|c|}
\hline \multirow[b]{2}{*}{ 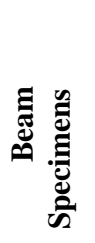 } & \multicolumn{6}{|c|}{ Longitudinal Reinforcement } & \multicolumn{6}{|c|}{ Concrete (Compression) } \\
\hline & 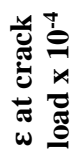 & 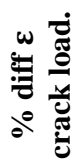 & $\begin{array}{l}\vec{a} \\
\vec{\omega}\end{array}$ & $\begin{array}{l}\omega \\
= \\
0 \\
0\end{array}$ & $\begin{array}{l}\hat{b} \\
\vec{x} \\
\vec{\omega}\end{array}$ & 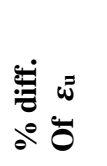 & 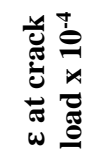 & 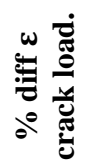 & $\begin{array}{l}\overrightarrow{\hat{\theta}} \\
\vec{\omega}\end{array}$ & $\begin{array}{l}\omega \\
\vdots \\
\vdots \\
0\end{array}$ & $\frac{3}{\vec{a}}$ & 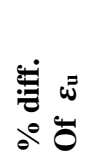 \\
\hline A-1 & 0.62 & ---- & 2.65 & --- & 3.26 & --- & -0.840 & --- & -1.25 & --- & -2.17 & --- \\
\hline $\mathrm{B}-2$ & 1 & 61.3 & 2.240 & -15.470 & 3.59 & 10.1 & -1.260 & 50 & -1.11 & -11.70 & -1.93 & -11.16 \\
\hline APH6 & 0.5 & --- & 2.33 & -- & 3.944 & --- & -0.58 & -- & -0.742 & --- & -2.02 & --- \\
\hline BPH6 & 0.89 & 78 & 2.441 & 4.71 & 3.1459 & -20.25 & -0.82 & 28.23 & -0.787 & 6.064 & -2.06 & 1.828 \\
\hline
\end{tabular}

\subsection{Crack pattern}

The tested specimens of beams at various stages of loading as sown in figures $(3,4,5$ and 6 ), the following conclusions can be pointed out from those figures:

1. The cracks order of formation was observed to be random as a result of constant moment that has been applied within the beam middle third region, and as the applied load increased, cracks grew upward accordingly.

2. Within the beam middle third area, the cracks seem to be vertical, this can be attributed to the pure bending moment that apply on this segment of the specimen. Outside this segment the cracks become slightly inclined, this can be attributed to the existence of shear forces besides the bending moment for beam A-1.
3. Since the highest moments was existed in the middle third of the beam, then this segment witnessed the first cracks.

\subsubsection{First crack width}

On the basis of results as shown in table (8) that the crack width at midpoint of the specimens at loads corresponding to crack and yield was the maximum crack width if compared with other cracks. Three principal cracks were dominated by the test under load points and in the centre of the beam for steel plate beams. The failure happens in a bending process with a concrete separation in the compression area. The first crack has been randomly appearing in the span middle third which was the zone that has the maximum moment, and in necessary the widest one.

Table 8: First crack width and number of cracks

\begin{tabular}{cccccc}
\hline Specimen designation & \multicolumn{2}{c}{ 1st Crack at cracking } & \multicolumn{2}{c}{ 1st Crack at yield } & $\begin{array}{c}\text { Crack width at failure } \\
\text { Measured by a ruler (mm) }\end{array}$ \\
\cline { 2 - 5 } & $\begin{array}{c}\text { Load } \\
(\mathbf{k N})\end{array}$ & $\begin{array}{c}\text { Width } \\
(\mathbf{m m})\end{array}$ & $\begin{array}{c}\text { Load } \\
(\mathbf{k N})\end{array}$ & $\begin{array}{c}\text { Width } \\
(\mathbf{m m})\end{array}$ & \\
\hline A-1 & 45 & 0.03 & 215 & 2.4 & 4 \\
APH6 & 30 & 0.01 & 105 & 1.5 & 10 \\
B-2 & 60 & 0.04 & 270 & 0.4 & 1.8 \\
BPH6 & 45 & 0.02 & 160 & 0.5 & 9 \\
\hline
\end{tabular}




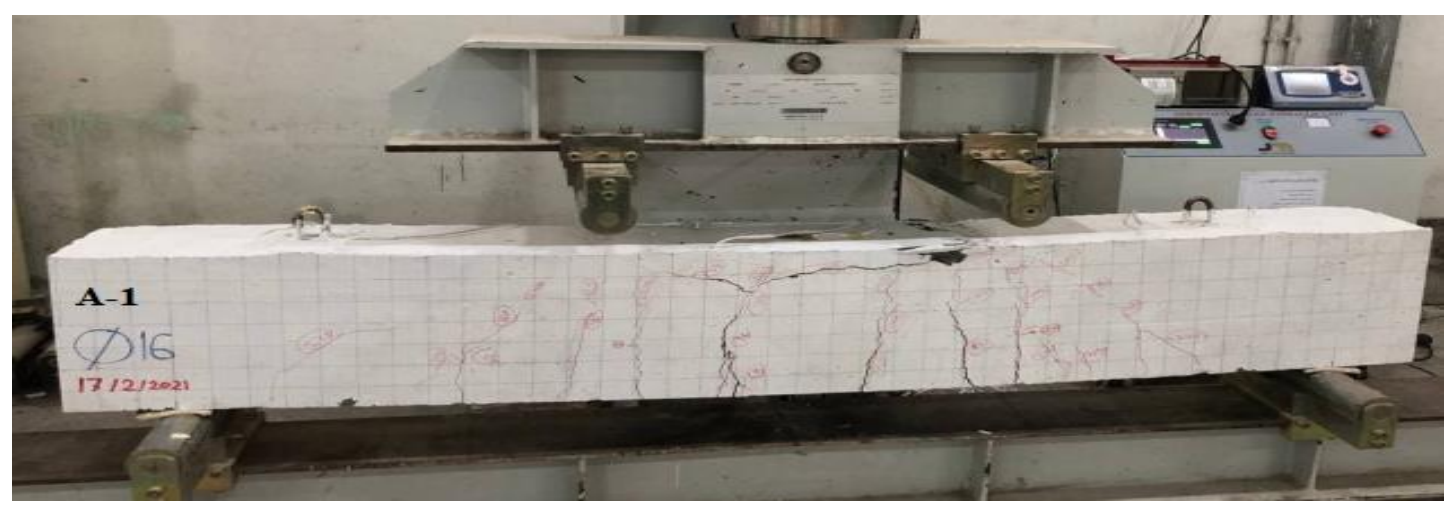

Figure 5. Crack pattern of A-1

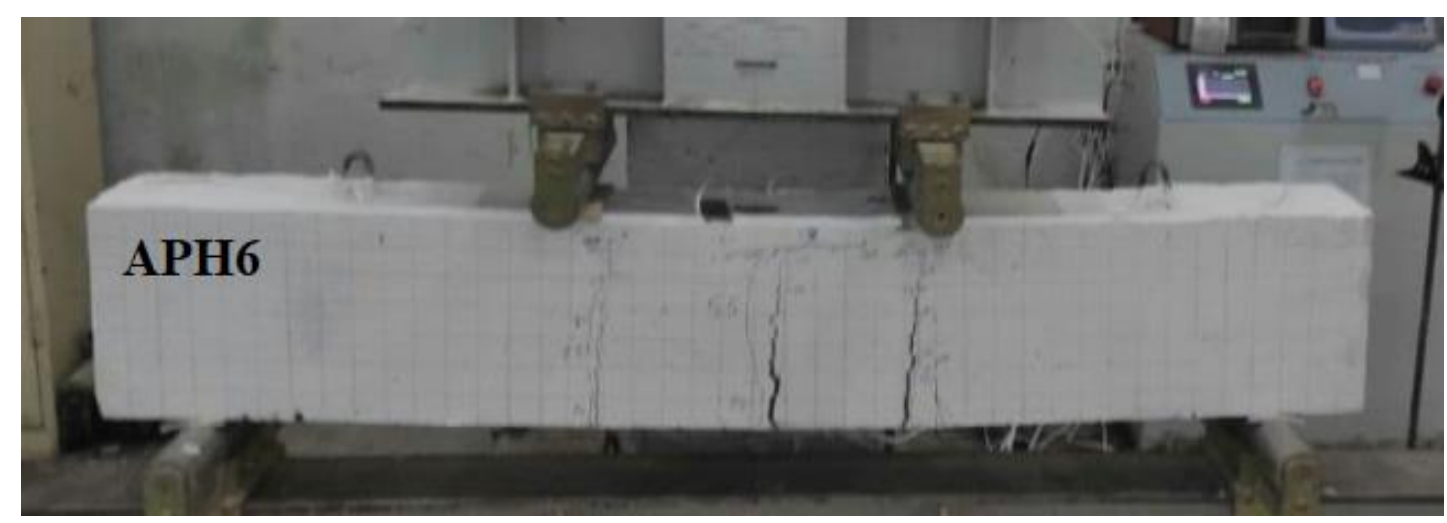

Figure 6. Crack pattern of APH6

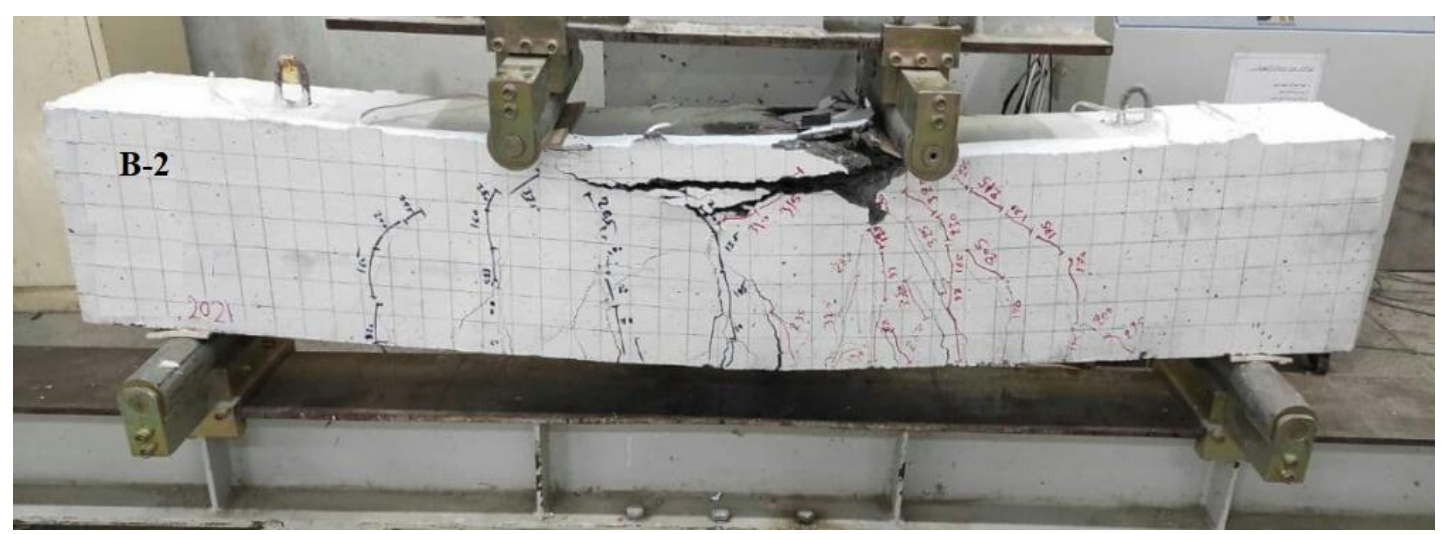

Figure 7. Crack pattern of B-2.

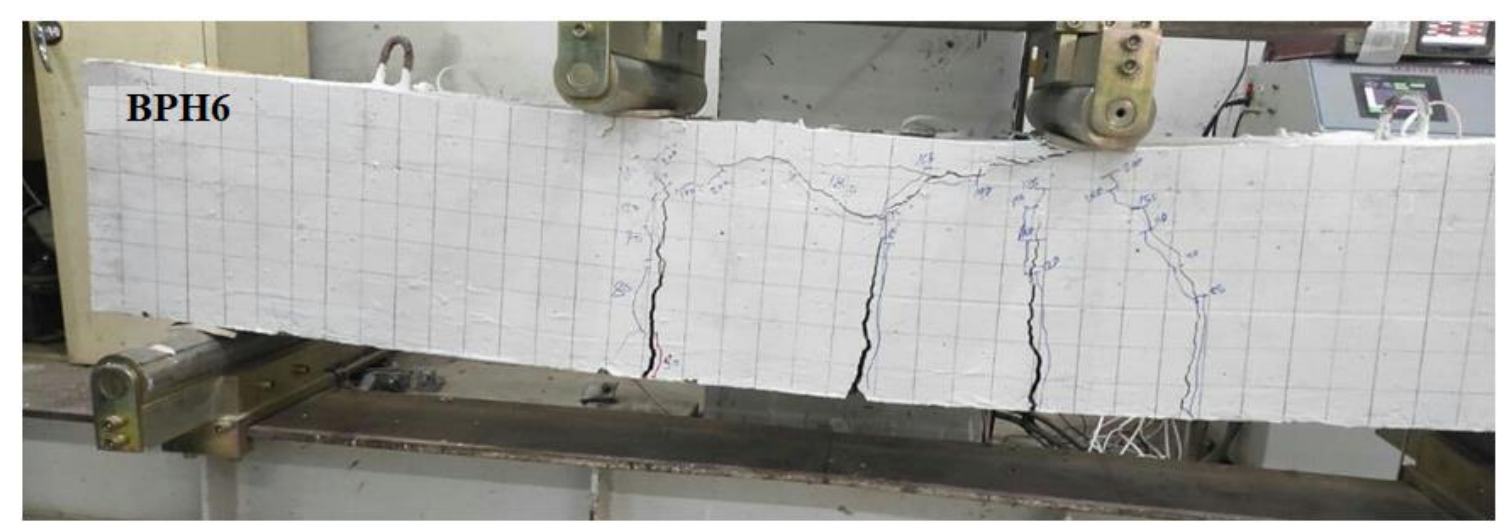

Figure 8. Crack pattern of BPH6 


\section{Conclusion}

1. With replacing the main reinforcement by steel plate there was a reduction in crack load, yield load, and ultimate load as compared to reference beam.

2. The crack load, yield load and ultimate load measured increased with increasing the cross-sectional area of the steel. Once, the increment in crack load and yield load were $25.5 \%$ and $16,67 \%$ more than that of reference specimens whereas the same increment was found in ultimate load for both steel bar and steel plate.

3. The measured crack load and ductility for steel plate was $16.7 \%$ more than steel bar when increasing cross-sectional area of steel.

4. The yield load for steel plate was $26.38 \%$ more than steel bar when increasing crosssectional area of steel.

5. Steel bar was $40 \%$ stronger than steel plate, whereas the deflection past of failure for steel plate has a considerable deflection before failure than steel bar. The deflection past the failure load was increased with increasing steel plate thickness.

6. The deflection at yield load and ultimate load were increased with increasing the cross-sectional area.

7. The strain in longitudinal steel plate at cracking load was increased with increasing cross-sectional area of steel whereas for steel bar was decreased with increasing area of steel.

8. The cracks are wider and less number for all the steel plate specimens compared to references specimens.

\section{References}

[1] Alfeehan, A. (2014). Strengthening of RC beams by external steel plate using mechanical connection technique. Journal of Engineering and Development, 18(1), 202-215.

[2] Thamrin, R., \& Sari, R. P. (2017). Flexural capacity of strengthened reinforced concrete beams with web bonded steel plates. Procedia engineering, 171, 1129-1136.
[3] Mansor, A. A., Ibrahim, A. M., \& Hamood, M. J. (2018). Study the Response of Bubbled Wide Reinforced Concrete Beams with Different Shear Steel Plate Spacing. Diyala Journal of Engineering Sciences, 11(2), 1-13.

[4] Mansor, A. A., Mohammed, A. S., \& Mansor, M. A. (2020). Reinforced Concrete Beams Capacity with Various Concrete Compressive Strengths. In IOP Conference Series: Materials Science and Engineering (Vol. 978, No. 1, p. 012036). IOP Publishing.

[5] Mansor, A. A., Mohammed, A. S., \& Salman, W. D. (2020). Effect of longitudinal steel reinforcement ratio on deflection and ductility in reinforced concrete beams. In IOP Conference Series: Materials Science and Engineering (Vol. 888, No. 1, p. 012008). IOP Publishing.

[6] Hadi, M. N., Sarhan, M. M., \& Teh, L. H. (2018). Behavior of Concrete Beams Reinforced with Steel Plates. ACI Structural Journal, 115(5), 13071315.

[7] Zuhdiy, Z. S., \& Abbas, A. L. (2021). Comparative Study of Structural Behaviour of Reinforced Concrete Box Girder with Different Numbers of Cells. In IOP Conference Series: Materials Science and Engineering (Vol. 1076, No. 1, p. 012110). IOP Publishing.

[8] ASTM C150/C150M-16e1. (2016). Standard Specifications for Portland Cement. West Conshohocken, PA: American Society for Testing and Materials.

[9] ASTM C192 / C192M-19. (2019), Standard Practice for Making and Curing Concrete Test Specimens in the Laboratory. West Conshohocken, PA: American Society for Testing and Materials.

[10] ASTM, C39. (2003). Standard specification for testing method for compressive strength of cylindrical concrete specimens. Philadelphia, PA: American Society for Testing and Materials.

[11] Hussain, L. N., Mohammed, A. S., \& Mansor, A. A. (2020). Finite Element Analysis Of Large-Scale Reinforced Concrete Shell Of Domes. Journal of Engineering Science and Technology, 15(4), 2712-2729.

[12] Mansoor, A. A., Salman, W. D., \& Abbas, A. L. (2006). Finite Element Analysis of Reinforced 
Concrete Deep Beams Strengthened in Shear with CFRP.

[13] Hadi, N. S., Oleiwi, S. M., Salman, W. D., Ibrahim, A. M., \& Mansor, A. A. (2020). Modified geopolymer paste adhesive bond material for near surface mounted strengthening technique. In IOP Conference Series: Materials Science and Engineering (Vol. 888, No. 1, p. 012053). IOP Publishing.

[14] Salman, W. D., \& Mansor, A. A. (2021). Fibrous geopolymer paste composites for near-surfacemounted strengthening of reinforced concrete beams in flexure. Case Studies in Construction Materials, 14, e00529. 